\title{
Influence of whole and sub soil salinity on growth, development, physiology and yield of selected rice varieties cultivated in Jaffna district, Sri Lanka.
}

\author{
L.Pradheeban $^{*}$, S.P.Nissanka ${ }^{1}$ and L.D.B.Suriyagoda ${ }^{1}$ \\ Postgraduate Institute of agriculture, \\ University of Peradeniya, \\ Sri Lanka.
}

\begin{abstract}
Growth and yield reduction of rice is a serious issue in salinity prone areas of the world. Rice yields decrease by $12 \%$ for every unit $\left(\mathrm{dSm}^{-1}\right)$ increase in EC above 3 $d \mathrm{Sm}^{-1}$. Salt in different soil depths influence the yield by interfering growth, development and physiology of plants. Impact of sub and whole soil salinity levels on yield are necessary for adapting salinity mitigation management practices. Study was carried out to identify the influence of whole and sub soil salinity levels on growth, development, physiology and yield of selected rice varieties cultivated in Jaffna district of Sri Lanka for salt tolerance. Experiment was conducted in the poly-tunnel of the Department of Crop Science, Faculty of Agriculture, University of Peradeniya during the period from June to November, 2014. Experiment was conducted as two factor factorial (varieties and depth of salinity of soil column) in completely randomized design with three replicates. Plant height, SPAD reading, shoot root ratio, root length, sodium potassium ratio, thousand grain weight and yield were measured. Data were analysed using Proc ANOVA procedure followed by the LSMEANS procedure for mean separation. Growth and yield of rice varieties were significantly affected under sub and whole salinity conditions. Within the same salinity levels, sub soil condition (top $15 \mathrm{~cm}$ normal soil and rest $45 \mathrm{~cm}$ saline soil) showed better performance in all parameters tested than whole soil salinity conditions (up to $60 \mathrm{~cm}$ saline soil). With the increased soil electrical conductivity, growth and yield reduction was observed in all tested varieties both in sub and whole soil salinity levels. Among the varieties, Pachaperumal showed the highest yield and tolerant to higher salinity levels followed by Adakari.
\end{abstract}

Keywords: electrical conductivity, growth, salt tolerance, sub and whole soil salinity, yield.

\section{INTRODUCTION}

Salinity is one of the major abiotic stresses limiting profitability of crop production worldwide (Tavakkoliet al., 2011). Salinity stress involves changes in various physiological and metabolic processes, depending on the severity and duration of the stress and ultimately inhibits crop production (Rahnama, 2010). Growth and yield reduction of crops is a serious issue in salinity prone areas of the world (Ashraf, 2009). Several physiological pathways such as photosynthesis, respiration, nitrogen fixation and carbohydrate metabolism have been observed to be affected by high salinity (James et al., 2011).

\footnotetext{
1 Department of Crop Science, Faculty of Agriculture, University of Peradeniya, Sri Lanka

* Author for correspondence: loha_p@yahoo.com
} 
Salt tolerance is the ability of plants to grow and complete their life cycle on a substrate that contains high concentrations of soluble salt (Parida and Das, 2005). All plants are sensitive to salts at some concentration. The limiting concentration changes with plant species, variety and stage of development and duration of the salt stress (Eynard et al., 2005). Rice (Oryza sativa L.) is one of the most important crops in the world and it is the primary staple food for over two billion people. Asian rice (sativa) is largely sensitive to salt stress leading to sizeable decline in productivity under salinity (Kumar et al., 2008). As previously found, if the $\mathrm{EC}$ value is higher than $4 \mathrm{dSm}^{-1}$ rice crop will be damaged permanently. Some traditional rice verities tolerant to salinity can be grown up to EC values of 6 to $8 \mathrm{dSm}^{-1}$, but most of the modern verities except At 354 and At 401 cannot be grown beyond a salinity level of $3 \mathrm{dSm}^{-}$ ${ }^{1}$ (Mapa et al., 2005)). Even at EC levels of $2 \mathrm{dSm}^{-1}$ in the saturated paste, the EC near the roots may be higher and the susceptible crops will be affected in numerous ways. One of the main aims of the salt tolerance studies is to increase the water use efficiency (WUE) under salinity. Selection of salt tolerant varieties is one of the most effective methods to increase the productivity.

$\mathrm{Na}^{+}$and $\mathrm{Cl}^{-}$are the principal ions in majority of salt affected soils, which mainly affect plants growth. Rice readily absorbs $\mathrm{Na}^{+}$due to its small sized which is distributed in all plant organs to pose ion damage, osmotic stress and imbalance nutrition (Siringam et al., 2011). Applied salinity caused an increase in $\mathrm{Na}^{+}$contents at the expense of $\mathrm{K}^{+}$contents in all rice genotypes under salt stress leading to decreased $\mathrm{K}^{+} / \mathrm{Na}^{+}$ratio. However, different rice genotypes behaved differently in this regard due to their divergent genetic makeup; and the more salt resistant genotypes maintained higher $\mathrm{K}^{+} / \mathrm{Na}^{+}$ratio against the sensitive ones(Dionisio-Sese and Tobita, 1998).

Current guidelines (Maas and Grattan, 1999) indicate that rice yields decrease by $12 \%$ for every unit of $\mathrm{dSm}^{-1}$ increase in EC (average root-zone EC of saturated soil extract) above 3.0 $\mathrm{dSm}^{-1}$. Studying salt levels in different layers of root zone and their influence on crop production are essential to adopt salinity mitigation measures to control salinity. Fewer studies have been conducted regarding the influence of salt on different layers of soil and its effect on crop productivity in Sri Lanka and none of the studies was exploited in paddy fields of northern part of Sri Lanka. Therefore, this study was carried out to identify the influence of whole and sub-soil salinity on growth, development, physiology and yield of selected rice varieties cultivated in Jaffna district of Sri Lanka for salt tolerance.

\section{METHODOLOGY}

\section{Experiment location}

Experiment was conducted in the poly-house of the Department of Crop Science, Faculty of Agriculture, University of Peradeniya during the period from June to November, 2014.The average day/night temperatures were $30 / 20^{\circ} \mathrm{C}$ and day time relative humidity of at least 60 $\%$ during the study period.

\section{Experimental design}

Experiment was conducted as a two factor factorial completely randomized design with three replicates. The factor one was depth of soil with different levels of salinity ( 4 and $6 \mathrm{dSm}^{-1}$ ) and factor two was varieties. Sodium chloride was used to represent different levels of salinity while control did not receive any salt. Pots were filled with soil containing different 
salt concentrations either to the whole pot (salinity throughout the soil profile) or filled up to $45 \mathrm{~cm}$ and rest topped up with normal soil (sub soil salinity condition). Five varieties were selected based on the stress response results of the previous experiments representing salt sensitive (Bg 352), salt tolerant traditional or introduced (Pokkali, Pachaperumal and Adakari) and salt tolerant new improved variety (At 353). Paddy seeds were collected from Paranthan (Adakari) and Batalagoda Rice Research and Development Institute (Pokkali, Pachaperumal, At 353 and $\mathrm{Bg}$ 352) from foundation seeds lot.

\section{Description of the experiment}

Soil was taken from salt affected farmer field of Ariyalai in Jaffna district, air dried and sieved using a $2 \mathrm{~mm}$ wire mesh. A preliminary soil electrical conductivity (EC) adjustment was done to increase the soil $\mathrm{EC}$ by using $\mathrm{NaCl}$. Then required amounts of $\mathrm{NaCl}$ salt were added to raise the EC to 4 and 6 in the soil column. Seventy centimeters long with $12 \mathrm{~cm}$ diameter PVC columns were used as pots. Bottom end of the pipes were sealed by an end cap using silicone gel. To prevent the leakage of water outside in addition to seal by end cap, $75 \mathrm{~cm}$ long 30 gauge thick polythene bag of $12 \mathrm{~cm}$ diameter was placed inside the pots. Same amount of sieved soil treated with $\mathrm{NaCl}$ salt was added $(7 \mathrm{~kg})$ to each pot to fill the whole soil column $(60 \mathrm{~cm})$ and $5.25 \mathrm{~kg}$ sieved soil treated with salt for sub soil $(45 \mathrm{~cm})$ and rest of the column was filled (up to $60 \mathrm{~cm}$ ) with non-salted soil. Pots were incubated for two weeks. Treatment combinations are given in Table 1.

Table 1. Different treatments with soil depth and EC levels of the experiment

\begin{tabular}{lccc}
\hline Treatments & $\begin{array}{c}\text { Electrical Conductivity } \\
\left(\mathbf{d S m}^{-\mathbf{1}}\right)\end{array}$ & $\begin{array}{c}\text { Electrical Conductivity } \\
\left(\mathbf{d S m}^{-\mathbf{1}}\right)\end{array}$ & Salt \\
\hline T1 & Normal good soil & Whole soil & Control \\
T2 & 4 & Sub soil & $\mathrm{NaCl}$ \\
T3 & 4 & Whole soil & $\mathrm{NaCl}$ \\
T4 & 6 & Sub soil & $\mathrm{NaCl}$ \\
T5 & 6 & Whole soil & $\mathrm{NaCl}$ \\
\hline
\end{tabular}

\section{Crop management}

Five pre-germinated seeds were planted in a pot and 2 weeks after planting, weak and excess seedlings were thinned out and three plants were allowed. Fertilizer application was done based on the recommendation made by the Department of Agriculture for dry and intermediate zones in year 2013 (Urea $175 \mathrm{~kg} / \mathrm{ha}$, TSP $35 \mathrm{~kg} / \mathrm{ha}$ and MOP $50 \mathrm{~kg} / / \mathrm{ha}$ ). Watering was done to keep the pot at saturated level based on the demand of the plant. To control stem borer and paddy bug carbosulfan and diamethoate was sprayed based on the Department recommendation. There was no serious disease incidence observed during the growing period.

\section{Measurements}

\section{Growth and physiological parameters}

Number of tillers per pot and plant height was measured at heading stage. Root length was measured at maturity stage.The SPAD - 502 chlorophyll meter (Konica Minolta) was used to acquire a rapid estimation of leaf chlorophyll content in fully expanded youngest leaf at maximum tillering and heading stages. Destructive plant samples were taken at heading stage to check dry weight, $\mathrm{Na}$ and $\mathrm{K}$ levels. 


\section{Yield parameters}

Root weight, shoot weight and grain yield were taken at physiological maturity stage.

\section{Calculation}

Shoot to root ratio and sodium to potassium ratio were calculated by dividing shoot weight by root weight and sodium concentration by potassium concentration, respectively.

\section{Data analysis}

Analysis was performed using Proc ANOVA procedure followed by the LSMEANS procedure for mean separation to identify the effects of soil depth based salinity and variety. All the significances were expressed at $\alpha=0.05$. Correlation analysis was done between shoot dry weight, root dry weight, root length, shoot to root ratio, leaf chlorophyll content and yield.

\section{RESULTS AND DISCUSSION}

\section{Number of tillers per pot}

The number of tillers per pot significantly varied due to the effects of salinity. There were no higher level interactions (salinity level $\times$ variety) in tiller number per pot between salt treatments and varieties. There was a significant difference among salt treatments on tiller number per pot. The highest tiller number was produced under normal soil condition (T1) followed by sub soil condition with $4 \mathrm{EC}$ (T2). The lowest tiller numbers were produced under whole soil condition with 6 EC (T5). There was no significant difference in tiller number per pot under normal soil (T1), sub soil condition with 4 EC (T2) and whole soil condition with 4 EC (T3). Similarly there was no significant difference in tiller number between subsoil conditions with 6 EC (T4) and whole soil condition with 6 EC (T5). But there was a significant difference between tiller number per pot under subsoil conditions of 4 and $6 \mathrm{EC}$ and whole soil conditions of 4 and $6 \mathrm{EC}$. This could be due to the salt levels affecting tiller production. Increased salt concentration decreased the tiller numbers. Within the same salt concentration, whole soil condition produced less tillers compared to sub soil conditions. The present result agrees with the findings of several researchers. Young et al., (2003) stated that the number of tillers per hill decreased with increasing salinity levels in rice.

There was a significant difference between varieties in tiller number per pot (Figure 1).Varieties Pachaperumal showed the highest tiller numbers followed by Pokkali and Bg 352 showed the lowest tiller number per pot. Tiller numbers between Adakari and At 353 was similar.

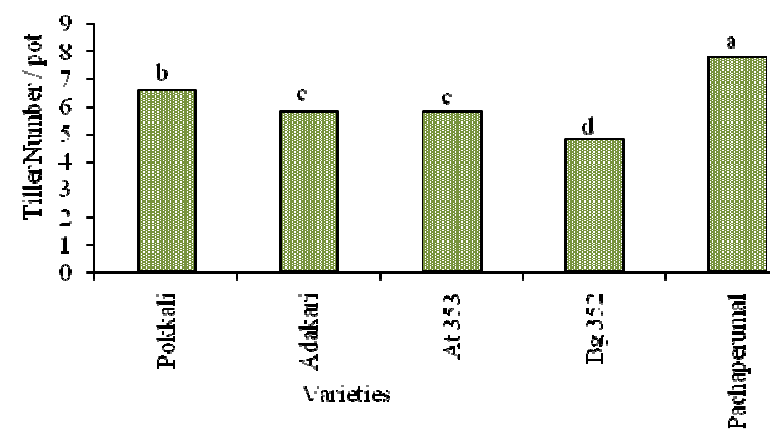

Fig. 1. Tiller number per pot for different varieties of rice 
Rice grain yields are highly dependent upon the number of panicle-bearing tillers produced per plant. Tiller production gradually decreases with the increased levels of salinity. Responses of crop to salinity at various growth stages are depended to the concentration and duration of exposure to salt condition in soil (Shereen et al., 2005).

\section{Plant height}

Plant height of each variety increased with their growth duration. There was no significant difference in higher level interactions between varieties and salinity levels in plant height. But there was a significant difference in plant height between varieties (Table 2 and 3), which might be due to inherent genetic potential of the genotypes of the varieties. In case of all the varieties, plant height decreased with increased in salinity levels.

Table 2. Mean plant height $(\mathrm{cm})$ among different salinity levels at heading stage

\begin{tabular}{lc}
\hline Treatments & Plant height (cm) \\
\hline T1(Normal) & $98.3^{\mathrm{a}}$ \\
T2 (Sub 4 EC) & $95.5^{\mathrm{a}}$ \\
T3 (Whole 4 EC) & $96.3^{\mathrm{a}}$ \\
T4 (Sub 6 EC) & $96.0^{\mathrm{a}}$ \\
T5 (Whole 6 EC) & $93.7^{\mathrm{a}}$ \\
\hline
\end{tabular}

Table 3. Mean plant height $(\mathrm{cm})$ among varieties at heading stage

\begin{tabular}{lc}
\hline Varieties & Plant height (cm) \\
\hline Pokkali & $104.1^{\mathrm{B}}$ \\
Adakari & $81.4^{\mathrm{D}}$ \\
At 353 & $79.3^{\mathrm{D}}$ \\
Bg 352 & $92.1^{\mathrm{C}}$ \\
Pachaperumal & $123.0^{\mathrm{A}}$ \\
\hline
\end{tabular}

Pachaperumal showed the highest plant height $(123 \mathrm{~cm})$ followed by Pokkali $(104 \mathrm{~cm})$ and At 353 showed the lowest plant height of $79 \mathrm{~cm}$. There was no significant difference in plant height between Adakari and At 353. Several studies showed that salinity influences the height of plants. Kumar et al., (2009) evaluated 11 varieties of rice under saline conditions and found that tolerant varieties have greater plant height and dry matter weight. Shalhevet, (1995) reported that salinity generally reduces the shoot growth of crops more than root growth, based on dry weight rather than length measurements. Islam et al., (2007) also observed the differences in plant height of rice varieties with different salinity levels. According to Bohnertet al., (1995) the chemical potential of the saline solution initially establishes a water potential imbalance between the apoplast and the symplast which leads to decrease in turgor that results into growth reduction.

\section{SPAD reading}

SPAD reading increased with growth duration of rice varieties. Chlorophyll meter (SPAD) is a convenient tool to estimate leaf nitrogen concentration of rice plant. It is a simple, quick, and nondestructive method (Peng et al., 1993). There was no significant difference in higher level interactions between varieties and salinity levels in SPAD reading. Among the varieties, there was no significant difference in SPAD value at tillering, but there was a 
significant difference at heading stage (Table 4 and 5). There was no significant difference between Pachaperumal and At 353 in SPAD value at heading stage. Similarly, there was no significant difference between Pokkali, Adakari and $\mathrm{Bg} 352$ at heading stage. Variety Pachaperumal showed the highest SPAD value in both stages and $\mathrm{Bg} 352$ showed the lowest. There were significant differences in SPAD value in normal soil (control) and sub soil salinity level of 4 EC and 6 EC (Table 3 and 4), but there were no significant differences in SPAD value in whole $4 \mathrm{EC}$, sub $6 \mathrm{EC}$ and whole $6 \mathrm{EC}$.

Table 4. SPAD value of different varieties at maximum tillering and heading stages

\begin{tabular}{lcc}
\hline Variety & Tillering stage & Heading stage \\
\hline Pokkali & $34.83^{\mathrm{a}}$ & $38.84^{\mathrm{B}}$ \\
Adakari & $34.98^{\mathrm{a}}$ & $38.02^{\mathrm{B}}$ \\
At 353 & $35.30^{\mathrm{a}}$ & $42.00^{\mathrm{A}}$ \\
Bg 352 & $34.74^{\mathrm{a}}$ & $38.00^{\mathrm{B}}$ \\
Pachaperumal & $36.05^{\mathrm{a}}$ & $42.00^{\mathrm{A}}$ \\
\hline
\end{tabular}

But there was no significant difference in SPAD value in 4 EC levels of sub and whole soil salinity conditions and $6 \mathrm{EC}$ levels of sub soil and whole soil salinity conditions. The highest SPAD value was observed under normal soil condition in all varieties at tillering and heading stages.

Table 5. PAD value of different salinity levels at maximum tillering and heading stages

\begin{tabular}{lcc}
\hline Salt Treatment $\left(\mathbf{d S m}^{-1}\right)$ & Tilleringstage & Headingstage \\
\hline T1(Normal) & $37.70^{\mathrm{a}}$ & $42.12^{\mathrm{A}}$ \\
T2 (Sub 4 EC) & $36.06^{\mathrm{b}}$ & $40.72^{\mathrm{B}}$ \\
T3 (Whole 4 EC) & $34.87^{\mathrm{bc}}$ & $39.35^{\mathrm{C}}$ \\
T4 (Sub 6 EC) & $34.13^{\mathrm{cd}}$ & $38.90^{\mathrm{C}}$ \\
T5 (Whole 6 EC) & $33.14^{\mathrm{d}}$ & $38.37^{\mathrm{C}}$ \\
\hline
\end{tabular}

SPAD values are closely correlated with leaf $\mathrm{N}$ concentration (Peng et al., 1995). Salt stress reduced the chlorophyll content and the extent of the reduction depends on salt tolerance of plant species. For example, it is generally known that in salt tolerant species, chlorophyll content increases, whereas it decreases in salt-sensitive species under saline regimes (Akram and Ashraf, 2011).Therefore, an accumulation of chlorophyll has been proposed as one of the potential biochemical indicators of salt tolerance in different crops.

\section{Shoot to root ratio}

Shoot to root ratio decreased with increasing salinity levels. There was no significant difference at higher level interactions between varieties and salinity levels (Figures 3 and 4). But there was a significant difference between varieties in shoot root to ratio. Variety Pachaperumal showed the highest shoot root ratio and significantly different from other varieties. Pokkkali showed the lowest shoot to root ratio. Even though, there was no significant difference among salinity levels, varieties grown in normal soil condition showed the highest shoot to root ratio of 3.22 and whole soil condition with 6 EC showed the lowest shoot to root ratio of 2.2. 
Varieties grown in normal soil (T1) showed the highest shoot to root ratio compared to salinity levels. Varieties grown under salinity level of 6 EC under whole soil (T5) showed the lowest shoot root ratio. Pokkali reduced its shoot to root ratio implying higher root growth compared to shoot growth while variety Pachaperumal increased their shoot growth compared to root growth. Pokkali produced more roots which helps the plant to absorb more water to tolerate salt levels.

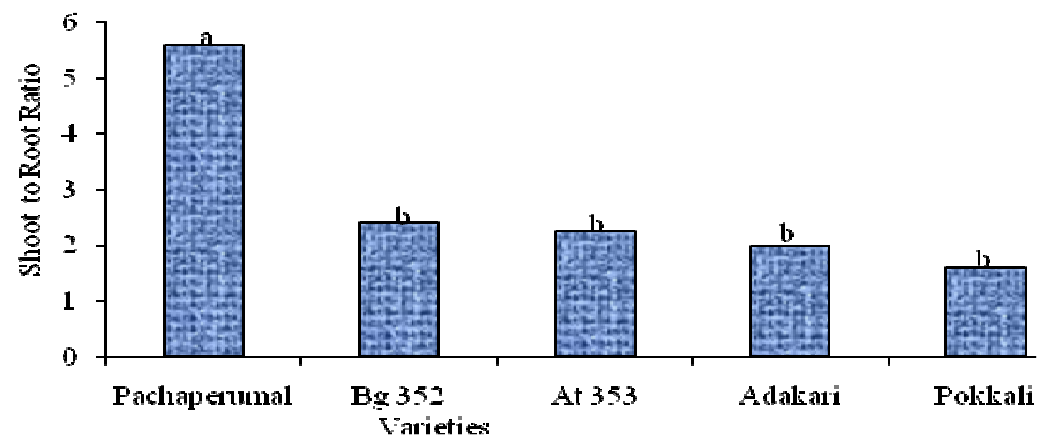

Fig. 3. Shoot to root ratio between different varieties of rice

Bauciet al., (2003) found an average shoot to root ratio as 5.7 in S-5 barley genotype which was gradually declined to 2.9 with increasing $\mathrm{NaCl}$ concentrations. Tattiniet al., (1995) noticed a decrease in shoot to root ratio in olive plants. He further concluded that such an increase was due to the rapid reduction of shoot dry matter production as a result of $\mathrm{NaCl}$ salinity stress. Similarly, the decrease in shoot to root ratio due to $\mathrm{NaCl}$ salinity stress has been reported by Ping et al., (2005) in Lycopersiconesculentum.

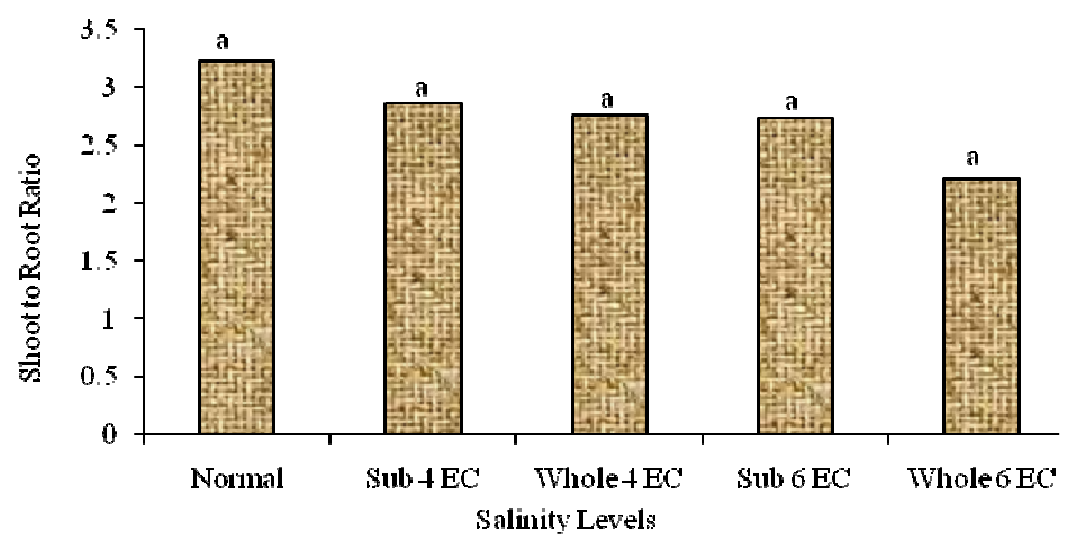

Fig. 4. Shoot to root ratio between different salt levels in rice.

\section{Root length:}

Root length of varieties decreased with increasing salinity levels. There was no significant difference at higher level interactions between varieties and salinity levels. But there was a significant difference between varieties and salinity levels in root length (Figure 5).

Variety Adakari showed the highest root length followed by At 353 and Pokkali, respectively. This was the adaptation of Adakari to tolerate drought as well as salinity levels. 
Pachaperumal showed the lowest root length. There was no significant difference between Bg 352 and Pokkali in root length. Higher root lengths favour the rice plant to absorb water from deeper layers to tolerate stress conditions. Varieties grown in normal soil (T1) showed the highest root length compared to different salinity levels and varieties grown under salinity level of 6 EC under whole soil (T5) showed the lowest root length. Stimulation of root length with increasing salt levels has been documented in many grass species, including barley (Bauciet al., 2003) and Triticumaestivum(Maghsoudi and Maghsoudi, 2008). Research showed that the shoot and root length of the $P$. alopecuroides was stimulated at lower levels of salinity. At higher levels of salinity, inhibition in shoot length and root length was observed which might be due to the toxicity of sodium chloride.

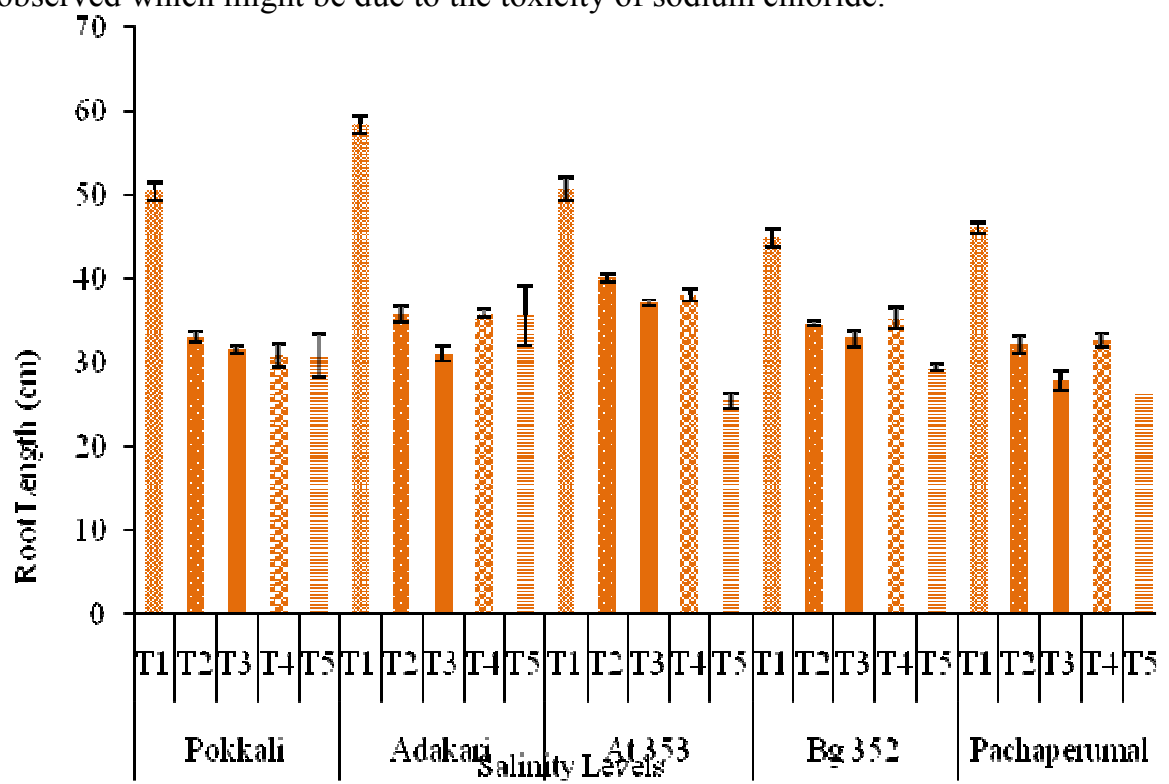

Fig. 5. Root length (cm) differences per plant of varieties under different salt levels (Error bars denote the standard error).

\section{Sodium to potassium ratio in shoot}

Sodium to potassium ratio varied with varieties and salinity levels. There was a significant difference at higher level interactions between varieties and salinity levels (Table 6 and 7).In all varieties, higher sodium to potassium ratio was observed in whole soil salinity level of 6 EC. Pachaperumal showed the lowest sodium to potassium ratio followed by Adakari in normal and sub soil condition of 4 EC. In general, tolerance of a crop variety was found to be associated with its ability to restrict potentially toxic ion uptake like $\mathrm{Na}^{+}$and associated with preferential uptake of the balancing ion like $\mathrm{K}^{+}$. Although the uptake of both $\mathrm{Na}$ and $\mathrm{K}$ is entirely independent, but lower $\mathrm{Na} / \mathrm{K}$ ratio is considered as desirable trait as it maintains the ion balance.

Table 6. Sodium to potassium ratio for different rice varieties at heading stage. 


\begin{tabular}{ll}
\hline & Na/K Ratio \\
Variety & \\
Pokkali & $2.5^{\mathrm{a}}$ \\
Adakari & $1.2^{\mathrm{c}}$ \\
At 353 & $1.9^{\mathrm{b}}$ \\
Bg 352 & $1.6^{\mathrm{b}}$ \\
Pachaperumal & $1.7^{\mathrm{b}}$ \\
\hline
\end{tabular}

Table 7. Sodium to potassium ratio for different salinity levels at heading stage.

\begin{tabular}{ll}
\hline Salinity levels & Na/K Ratio \\
\hline Normal (T1) & $1.5^{\mathrm{c}}$ \\
Sub 4 EC (T2) & $1.5^{\mathrm{c}}$ \\
Whole 4 EC (T3) & $2.0^{\mathrm{b}}$ \\
Sub 6 EC (T4) & $1.5^{\mathrm{c}}$ \\
Whole 6 EC (T5) & $2.4^{\mathrm{a}}$ \\
\hline
\end{tabular}

Decrease in tissue content of $\mathrm{Na}^{+}$and increased one of $\mathrm{K}^{+}$is an important indicator of salt resistance (Hu and Schmidhalter, 1997). The ability of plants to limit $\mathrm{Na}^{+}$transport into shoot is important for the maintenance of growth rates and protection of the metabolic process in elongation cells from the toxic effect of $\mathrm{Na}^{+}$(Razmjooet al., 2008). The roots of rice plants freely absorb $\mathrm{Na}^{+}$due to its small sized molecules which are finally distributed in all plant organs to pose ion damage, osmotic stress and imbalance nutrition (Siringamet al., 2011). Over accumulation of $\mathrm{Na}^{+}$is well reported in salt sensitive rice cultivars under high salinization and therefore, small accrual of $\mathrm{Na}^{+}$ions in tolerant rice cultivars under salinity explain the basis of $\mathrm{NaCl}$ resistance (Dionisio-Sese and Tobita, 1998).

\section{Thousand Grain Weight}

There was a significant difference between normal soil condition, sub soil conditions of 4 EC and $6 \mathrm{EC}$ and whole soil conditions of $4 \mathrm{EC}$ and $6 \mathrm{EC}$ (Table 8). The highest thousand grain weight was observed in normal soil condition (T1) and the lowest thousand grain weight was observed in whole soil condition of 6 EC. Among the varieties, significant differences were observed in 1000 grain weight due to salinity stress. There was a significant difference between Pachaperumal and other varieties. The highest thousand grain weight was observed in Pachaperumal and the lowest was observed in Pokkali and Adakari. This might be due to lower accumulation of carbohydrates and other food materials due to salt stress. Zaman et al (1997) reported that 1000 grain weight decreases with increasing levels of salinity.

Table 8. Average thousand grain weight for different varieties and different salinity treatments.

\begin{tabular}{l|c|c|c|c|c|c}
\hline & \multicolumn{6}{|c}{ Average thousand grain weight (g) } \\
\hline Varieties & Normal & $\begin{array}{c}\text { Sub 4 } \\
\text { EC }\end{array}$ & $\begin{array}{c}\text { Whole 4 } \\
\text { EC }\end{array}$ & $\begin{array}{c}\text { Sub } \\
\text { 6EC }\end{array}$ & $\begin{array}{c}\text { Whole 6 } \\
\text { EC }\end{array}$ & Mean \\
\hline Pokkali & 21.1 & 20.8 & 20.0 & 20.2 & 19.3 & 20.3 \\
Adakari & 21.4 & 20.8 & 20.0 & 20.2 & 19.2 & 20.3 \\
At 353 & 22.8 & 20.7 & 20.2 & 20.0 & 19.6 & 20.7 \\
Bg 352 & 22.7 & 20.9 & 20.2 & 20.0 & 19.4 & 20.6 \\
Pachaperumal & 26.8 & 24.9 & 24.5 & 23.7 & 23.3 & 24.6 \\
\hline
\end{tabular}




\begin{tabular}{l|l|l|l|l|l|l}
\hline Mean & 23.0 & 21.6 & 21.0 & 20.8 & 20.1 & \\
\hline
\end{tabular}

\section{Yield}

Yield of all the varieties treated with salt was reduced compared to normal (control). There was a significant difference in higher level interactions in yield between varieties and salinity levels (Table 9). Among varieties, Pachaperumal recorded the greatest yield followed by Adakari and At 353, respectively. There was no significant difference in yield between Adakari, At 353, Bg 352 and Pokkali. The lowest yield was observed in Pokkali. The highest yield was observed under normal soil followed by sub $4 \mathrm{dSm}^{-1}$, whole $4 \mathrm{dSm}^{-1}$, sub6 $\mathrm{dSm}^{-}$ ${ }^{1}$ and whole $6 \mathrm{dSm}^{-1}$, respectively.

Yield reduction was higher in whole soil treatments compared to subsoil treatments at the same electrical conductivity (EC). The highest yield reduction was observed in At 353 (33.7 $\%)$ followed by Adakari (28.60 \%) and Pokkali (25.03 \%) respectively at whole soil salinity of 6 EC. Young et al., (2003) reported that grain yield decreased with raising salinity.Grain yield reduction of rice varieties due to salt stress is also reported by Gain et al., (2004). Zeng and Shannon (2000) stated that reduction of tiller number due to salinity condition may affect grain yield per plant.

Table 9. Average yield per pot (g)of different rice varieties under different salt levels.

\begin{tabular}{l|c|c|c|c|c|c}
\hline & \multicolumn{7}{|c}{ Average Yield (g/pot) } \\
\hline Varieties & Normal & $\begin{array}{c}\text { Sub 4 } \\
\text { EC }\end{array}$ & $\begin{array}{c}\text { Whole 4 } \\
\text { EC }\end{array}$ & Sub 6EC & $\begin{array}{c}\text { Whole 6 } \\
\text { EC }\end{array}$ & Mean \\
\hline Pokkali & 38.94 & 31.53 & 31.48 & 29.41 & 29.20 & 32.11 \\
Adakari & 40.60 & 32.79 & 30.43 & 30.92 & 28.99 & 32.75 \\
At 353 & 41.12 & 33.15 & 30.89 & 30.68 & 27.27 & 32.62 \\
Bg 352 & 35.94 & 34.72 & 33.15 & 30.37 & 29.11 & 32.66 \\
Pachaperumal & 43.76 & 39.52 & 36.99 & 37.52 & 33.94 & 38.35 \\
\hline Mean & 40.07 & 34.34 & 32.59 & 31.78 & 29.70 & \\
\hline
\end{tabular}

There was a positive correlation between shoot dry weight, root dry weight and shoot to root ratio.

When plants are grown under saline conditions, as soon as the new cell starts its elongation process, the excess of salts modifies the metabolic activities of the cell wall causing the deposition of various materials which limit the cell wall elasticity. Further, cell wall becomes rigid and consequently the turgor pressure efficiency in cell enlargement is decreased. The other expected causes of the reduction in yield per plant, leaf area and yield components in rice could be the shrinkage of the cell contents, reduced development and differentiation of tissues, unbalanced nutrition, damage of membrane and disturbed avoidance mechanism. The reduction in leaf area, yield and yield components under saline conditions were also due to reduced growth as a result of decreased water uptake, toxicity of sodium and chloride in the shoot cell as well as reduced photosynthesis (Ali et al., 2004).

\section{CONCLUSION}


Different levels of salinity significantly affect the performance of different rice varieties. With the increase of salinity levels, the growth, yield components and yield was reduced in all tested varieties. Within the same salinity level, the sub soil condition showed better performance than whole soil salinity conditions. The difference is more prominent at higher salinity levels having whole soil column of 6 EC. When increasing the salt levels, Pokkali showed the lowest shoot to root ratio and Pachaperumalshowed the increased shoot to root ratio. Shoot sodium to potassium ratio varied among the tested varieties. Pachaperumal showed the lowest sodium to potassium ratio followed by Adakari in normal and sub soil condition of 4 EC. VarietyAdakari showed the highest root length, helped to tolerate the stress condition.Pachaperumal showed the highest yield and tolerance to higher salinity levels followed by Adakari.

\section{REFERENCES}

Akram, N.A. Ashraf, M. (2011). Improvement in growth, chlorophyll pigments and photosynthetic performance in salt-stressed plants of sunflower (Helianthus annuus L.) by foliar application of 5-aminolevulinic acid. - Agrochimica 55, 94 - 104.

Ali, Y. Aslam, Z. Ashraf, M.Y. and Tahir, G.R. (2004). Effect of salinity on chlorophyll concentration, leaf area, yield and yield components of rice genotypes grown under saline environment. International Journal of Environmental Science \& Technology Vol. 1, No. 3, pp. $221-225$

Ashraf, M. (2009). Biotechnological approach of improving plant salt tolerance using antioxidants as markers. Biotechnol. Adv., 27, 84 - 93.

Bauci, S.A. Ekuz, H. and A. Yilmaz (2003). Determination of the salt tolerance of some barley genotypes and the characteristics affecting tolerance. Turk. J. Agric., 27, 253 - 260.

Bohnert, H.J. Nelson, D.E. and Jensen, R.G. (1995). Adaptations to environmental stresses. Plant Cell, 7, 1099 - 1111.

Dionisio-Sese, M.L. and Tobita, S. (1998). Antioxidant responses of rice seedlings to salinity stress. Plant Sci., 135, 1 - 9.

Eynard, A. Lal, R. and Wiebe, K. (2005). Crop response in salt-affected soils. J. Sustain. Agric., 27, 5 - 50.

Gain, P. Mannan, M.A. Pal, P.S. Hossain, M.M. Parvin, S. (2004). Effect of salinity on some yield attributes of rice. Pak J BiolSci 7(5),760 - 762.

Hamada, A.M. and El-Enany, A.E. (1994). Effect of NaCl salinity on growth, pigment and mineral element contents, and gas exchange of broad bean and pea plants. Biol. Plant., 36, $75-81$.

$\mathrm{Hu}$, Y. and Schmidhalter, U. (1997). Interactive effects of salinity and macronutrient level on wheat. J. Plant Nutr., 20, 1169 - 1182.

Islam, M.Z, Baset Mia, M.A, et al. (2007). Effect of different saline levels on growth and yield attributes of mutant rice. J. Soil. Nature, 1(2), 18 - 22. 
Kumar, B. S.; Titov, S. Moffazzal Islam, M. Siddika, A. Sultana, S. ShahidulHaque, M. (2009). Phenotypic and genotypic screening of rice genotypes at seedling stage for salt tolerance. Global Journal of Biotechnology and Biochemistry, v. 4, n. 2, p. $126-131$.

Kumar, V. Shriram, V. Nikam, T.D. Jawaliand, N. Shitole, M.G. (2008). Sodium chloride induced changes in mineral elements in indica rice varieties differing in salt tolerance. J. Plant Nutr., 3, 1999 - 2017.

Maas, E.V. Grattan S.R. (1999). Crop yields as affected by salinity. In: Skaggs RW, van Schilfgaarde J (eds.). Agricultural Drainage.AgronMonogr 38. ASA, CSSA, SSA, Madison, WI. p 55-108.

Maghsoudi, A.M. and Maghsoudi, K. (2008). Salt stress effects on respiration and growth of germinated seeds of different wheat (Triticumaestivum L.) varieties. World J. Agric. Sci., 4, $351-358$.

Mapa, R.B. Wickramasinghe, W. A. D. B. Sirisena, D. N. Kendaragama, K. M. A. (2005).Salt in the soil. Soil Science Society of Sri Lanka. [Accessed on 05.01.2016]. Available at http://tsunami.obeysekera.net/documents/salt $\% 20 \mathrm{in} \% 20$ the $\% 20$ soil.pdf.

Munns, R. and Tester, M. (2008). Mechanisms of salinity tolerance.Annu. Rev. Plant Biol., $59,651-681$.

Parida, A.K. and Das, A.B. (2005). Salt tolerance and salinity effects on plants: A review. Ecotoxicol. Environ. Safe, 60, 324 - 349.

Peng, S., F. V. Garcia, R. C. Laza, and K. G. Cassman, (1993). “Adjustment for specific leaf weight improves chlorophyll meter's estimate of rice leaf nitrogen concentration," Agronomy Journal, vol. 85, no. 5, pp. 987-990.

Peng, S., M.R. Laza, F.V. Garcia, and Cassman, K.G. (1995). "Chlorophyll meter estimates leaf area-based nitrogen concentration of rice," Communications in Soil Science and Plant Analysis, vol. 26, no. 5-6, pp. 927-935.

Ping, A., S. Inanaga, X.J. Li, A.E. Eneji and Zhu, N.W. (2005). Interactive effects of salinity and air humidity on two tomato cultivers differing in salt tolerance. J. Plant Nutr., $28,459-473$.

Rahnama, A. James, R. A. Poustini, K. and Munns, R. (2010). Stomatal conductance as a screen for osmotic stress tolerance in durum wheat growing in saline soil," Functional Plant Biology, vol. 37, no. 3, pp. 255-263.

Razmjoo, K., P. Heydarizadeh and Sabzalian M.R. (2008). Effect of salinity and drought stresses on growth parameters and essential oil content of Matricaria chamomile. Inter. J. Agric. Biol., 10, 451 - 454.

Shalhevet, J. (1995). Root and shoot growth responses to salinity in maize and soybean. Agron J., 87, 512 - 516.

Shereen, A. Mumtaz, S. Raza, S. Khan, M.A. and Solangi, S. (2005). Salinity effects on seedling growth and yield components of different inbred rice lines. PakistanJournalofBotany, 37(1), 131 - 139. 
Siringam, K. Juntawong, N. Cha-um, S. Kirdmanee, C. (2011). Salt stress induced ion accumulation, ion homeostasis, membrane injury and sugar contents in salt-sensitive rice (Oryza sativa L. spp. indica) roots under iso-osmotic conditions. Afr. J. Biotechnol., 10, 1340 - 1346.

Tattini, M., R. Gucci, M.A. Coradeschi, C. Ponzio and J.D. Everard (1995). Growth, gas exchange and ion content in Olea europhea plants during salinity stress and subquent relief. Physiol. Plant., 98, 117 - 124.

Tavakkoli, E., F. Fatehi, S. Coventry, P. Rengasamy and G.K. McDonald, (2011). Additiveeffects of $\mathrm{Na}+$ and $\mathrm{Cl}-$ ions on barley growth under salinity stress. J. Exp. Bot., 62, $2189-2203$.

Young,W.C., KyuSeong, L., JongCheo, K., SongYeol, C. and C. DonHyang. (2003). Critical saline concentration of soil and water for rice cultivation on a reclaimed saline soil. Korean J. Crop Sci., 48(3), 238 - 242.

Zaman, S.K., Chowdhury, D.A.M. and Bhuiyan, N.I. (1997).The effect of salinity on germination, growth, yield and mineral composition of rice. Bangladesh J. Agril. Sci., 24(1), $103-109$.

Zeng, L. and Shannon, M.C (2000). Salinity effects on seedling growth and yield components of rice. Crop Science, 40, 996 - 1. 